\title{
Penentuan Pola Tanam Padi dan Jagung Berbasis Neraca Air di Kecamatan Lewa Kabupaten Sumba Timur
}

\author{
Design of Cropping Pattern of Paddy and Corn Based on Water Balance in Lewa District, Eastern Sumba Regency
}

\author{
Yonce M. Killa1*, Bistok Hasiholan Simanjuntak ${ }^{2}$, Nugraheni Widyawati² \\ ${ }^{1}$ Jurusan Magister IImu Pertanian, Fakultas Pertanian dan Bisnis Universitas Kristen Satya Wacana, \\ Jl. Diponegoro No. 52-60, Salatiga 50711, Indonesia \\ ${ }^{2}$ Fakultas Pertanian dan Bisnis Universitas Kristen Satya Wacana, Jl. Diponegoro No. 52-60, \\ Salatiga 50711, Indonesia \\ *Email: yoncekilla7@gmail.com
}

Tanggal submisi: 18 September 2018; Tanggal penerimaan: 30 November 2018

\begin{abstract}
ABSTRAK
Lewa adalah salah satu kecamatan di Kabupaten Sumba Timur Provinsi Nusa Tenggara Timur (NTT) dengan ciri lahan kering dan pertaniannya bergantung pada hujan. Komoditas utama yang dikembangkan adalah padi (Oriza sativa) dan jagung (Zea mays). Keterbatasan air mengharuskan perencanaan pola tanam yang tepat, salah satunya dengan analisis neraca air. Penelitian ini bertujuan untuk mengetahui kondisi neraca air dan menentukan pola tanam berbasis padi dan jagung di Kecamatan Lewa. Metode analisis yang digunakan yaitu menggunakan pemodelan neraca air menggunakan NRCS Java Newhall Simulation Model (jNSM). Hasil analisis neraca air dengan menggunakan software jNSM yang dipetakan menggunakan software Arcview menunjukan total ketersediaan air di Kecamatan Lewa terbagi menjadi 2 wilayah yaitu wilayah I dengan ketersediaan air $413 \mathrm{~mm} / \mathrm{tah} u n$ dan wilayah II dengan ketersediaan air $868 \mathrm{~mm} /$ tahun. Berdasarkan ketersediaan air tersebut, maka dapat dirancang pola tanam yaitu wilayah I hanya dapat ditanami satu kali dalam setahun, yaitu di musim hujan (Desember-April) dengan pilihan tanaman padi atau jagung, serta wilayah yang bisa ditanam 2 kali dengan pilihan tanaman jagungpadi/jagung-jagung.
\end{abstract}

Kata kunci: Pola tanam; padi; Kecamatan Lewa; neraca air; jagung

\begin{abstract}
Lewa is one of districts in East Sumba Regency, Nusa Tenggara Timur (NTT) Province. It is characterized by dry land, its agriculture depends on rain. The main commodities are Oryza sativa and Zeamays. Due to lack of water, the cropping pattern design is vital. One of methods for designing crroping pattern is water balance analysis. The aim of this study was to understand water balance status and to decide the cropping pattern based of paddy and corn farming in Lewa District. The NRCS Java Newhall Simulation Model (jNSM) was adopted for water balance modeling. The water balance status then was mapped by using the Arc view software for showing total water availability in Lewa district. There were two zones: I (water availability $413 \mathrm{~mm} / \mathrm{year}$ ) and II (water availability: $868 \mathrm{~mm} /$ year). Based on the water availability, the zone I could be designed one period a year in rainy season (December-April) with cropping option paddy or corn. While zone II could be planted two times with cropping option corn-paddy or corn-corn.
\end{abstract}

Keywords: Croping pattern; Oryzasativa; Lewa District; water balance; Zeamays

1

DOI: http://doi.org/10.22146/agritech.38896

ISSN 0216-0455 (Print), ISSN 2527-3825 (Online) 


\section{PENDAHULUAN}

Lewa merupakan salah satu kecamatan yang ada di Kabupaten Sumba Timur Provinsi Nusa Tenggara Timur (NTT). Daerah ini adalah besar usaha taninya merupakan pertanian lahan kering dengan sumber air utama dari curah hujan. Ketersediaan air dari daerah ini sangat terbatas akibat curah hujan yang rendah dan cenderung berkurang jumlahnya. Makaborang dkk. (2009) melaporkan bahwa curah hujan di Kabupaten Sumba Timur adalah rendah, dimana pada daerah ini hanya terjadi 3-4 bulan basah sedangkan bulan kering mencapai 8-9 bulan.

Masalah ketersediaan air bagi tanaman sangat menentukan keberhasilan kegiatan pertaniaan di daerah lahan kering seperti di Kecamatan Lewa. Hal ini dapat terjadi karena, kegiatan pertanian sangat ditentukan oleh perimbangan antara jumlah air yang tersedia di lahan dengan jumlah air yang dibutuhkan selama pertumbuhannya. Jumlah air yang tersedia pada suatu lahan pertanian dapat dilihat dari kondisi curah hujan, sedangkan jumlah air yang dibutuhkan tanaman dapat digambarkan dengan jumlah air yang dibutuhkan untuk evapotranspirasi (Hidayat dkk., 2006). Ketersediaan air tanah akan menentukan pertumbuhan dan hasil tanaman secara langsung, karena kekurangan air menyebabkan penurunan laju fotosintesis dan distribusi asimilat terganggu, serta berdampak negatif pada pertumbuhan tanaman baik pada fase vegetatif maupun fase generatif (Aqil dkk., 2008 dalam Simanjuntak dkk., 2016).

Jumlah air yang tersedia dan jumlah air yang dibutuhkan akan mengalami fluktuasi dari waktu ke waktu, sehingga pada suatu periode dapat terjadi kelebihan air dan pada periode lainnya terjadi kekurangan air bagi tanaman (Hidayat dkk., 2006). Salah satu cara untuk mengetahui fluktuasi ketersediaan air dari bulan ke bulan dapat diketahui dengan menggunakan neraca air antara besarnya masukan air hujan dan, kemampuan tanah menyimpan air dan keluaran dari evapotranspirasi potensial (Djufry, 2012). Neraca air merupakan perincian semua masukan, keluaran, perubahan simpan air yang terkandung di dalam tanah yang menggambarkan perolehan air (surplus atau defisit) dari waktu ke waktu (Hillel, 1972 dalam Paski dkk., 2018). Neraca air bermanfaat untuk melengkapi gambaran umum dari keadaan air pada suatu daerah (presipitasi, evapotranspirasi, kandungan air dan perubahan kelembaban tanah); menilai kemampuan suatu daerah untuk ditanami melalui pendugaan kebutuhan air bagi tanaman, menguji hubungan iklim atau cuaca dengan hasil produksi tanaman (Ayu dkk., 2013).
Ketersediaan air sangat berpengaruh terhadap pola tanam suatu daerah. Menurut Karamouz dkk. (2010), pola tanam dari suatu lahan pertanian dapat dioptimalkan sesuai dengan ketersediaan air di wilayah tersebut. Pola tanam merupakan suatu sistem pertanaman yang diusahakan di sebidang lahan yang meliputi cara dan jenis tanaman serta jadwal penanaman yang di selenggarakan dalam periode waktu tertentu (Karnadi, 2012). Utomo dkk. (2016) mengatakan, pola tanam didesain untuk menentukan kapan tanaman bisa secara efisien memanfaatkan ketersediaan air. Pola tanaman meliputi pemilihan tanaman yang kebutuhan airnya sesuai dengan sebaran curah hujan, dan rotasi tanaman yang mampu memanfaatkan curah hujan secara efisien. Jika musim hujannya pendek, tanaman yang dipilih yang berumur pendek. Sebaliknya, jika musim hujannya cukup panjang tanaman yang dipilih berumur panjang, atau dipilih dua tanaman di mana tanaman kedua dipilih yang tahan kekeringan (Utomo dkk., 2016).

Tanaman padi dan jagung merupakan dua dari sekian jenis tanaman yang termasuk dalam tanaman pangan utama. Dimana padi menjadi komoditi utama dengan luas tanam 2.046 ha dengan produksi 7.802 ton, sedangkan tanaman jagung dengan luas tanam 599 ha dengan produksi 1.848 ton (BPS, 2015). Produksi kedua tanaman ini dapat ditingkatkan dengan adanya informasi ketersediaan air dan pola tanam yang tepat,sehingga dapat dimaksimalkan lahan yang ada. Oleh karena itu penelitian ini bertujuan untuk 1) mengetahui kondisi neraca air Kecamatan Lewa; dan 2) menentukan pola tanam berbasis padi dan jagung di Kecamatan Lewa.

\section{METODE PENELITIAN}

\section{Waktu dan Tempat Penelitian}

Penelitian dilaksanakan pada Januari - April 2018 di Kecamatan Lewa Kabupaten Sumba Timur dan analisis sifat fisik tanah di lakukan di Laboratorium Tanah, Fakultas Pertanian dan Bisnis Universitas Kristen Satya Wacana.

\section{Alat dan Bahan}

Alat yang digunakan dalam penelitian ini adalah GPS dan alat-alat laboratorium untuk analisis tanah, serta software Arcview versi 3.2, QGIS versi 2.8, jNSM (Java Newhall Simulation Model, Version 1.6.0). Bahan yang digunakan adalah sampel tanah terusik dan tak terusik, data curah hujan selama 15 tahun, citra satelit Lansat 7 ETM+ (band 61 dan band 62), dan citra Lansat 8 OLI/TIRS Path/Row 118/065. 


\section{Prosedur Penelitian}

\section{Analisis curah hujan dan suhu udara}

Data curah hujan yang digunakan adalah data curah hujan tahun 2000-2015 yang diperoleh dari 7 stasiun klimatologi di Kabupaten Sumba Timur (Wanga, Tanarara, Ngongi, Malahar, Kananggar, Melolo dan Waingapu) dan 1 stasiun klimatologi di Kabupaten Sumba Tengah (Lindiwacu). Data suhu udara diperoleh dari perhitungan temperatur permukaan lahan (Land Surface Temperature), dengan menghitung spectral radiance $(L \lambda)$ dan temperature brightness menggunakan citra satelit Lansat 7 ETM+ (band 61 dan band 62) untuk tahun 2007-2012 dan citra Lansat 8 OLI/TIRS Path/Row 118/065 untuk tahun 2013-2017. Hasil foto citra satelit dianalisis dengan raster calculator dan raster statistic for poligon pada software QGIS. Data dari citra satelit kemudian dianalisis berdasarkan perhitungan suhu udara dalam Wiweka (2014).

\section{Analisis neraca air}

Salah satu permodelan untuk menentukan neraca air adalah menggunakan NRCS Java Newhall Simulation Model (jNSM) (Dauglas \& Brian, 2011). jNSM adalah model komputer dengan bahasa basic Java yang digunakan untuk penentuan rezim suhu tanah, rezim kelembaban dan evapotranspirasi potensial. Fungsi dasar dari model ini adalah mengambil data rata-rata suhu udara dan curah hujan kemudian mensimulasikan perilaku dari profil kelembaban. Model algoritma dari Newhall Simulation Model (NSM) didasarkan pada konsep pengisian ulang kelembaban horishontal dan pelepasan vertikal dalam profil tanah. Model ini sama seperti model kelembaban tanah lainnya dimana tanah dianggap sebagai reservoir dengan kapasitas tetap. Dalam model ini, air ditambahkan oleh curah hujan, jumlah yang melebihi kapasitas retensi tanah akan hilang oleh pencucian atau limpasan, dan air tanah yang tersimpan akan terhilang dengan evapotranspirasi. Model ini menggunakan prosedur Thornthwaite (1948) untuk memperkirakan evapotranspirasi dari data suhu dan panjang hari. Asumsi yang digunakan adalah hubungan infiltrasi, intesitas curah hujan, dan jumlah energi yang dibutuhkan untuk menghilangkan kelembaban dari lapisan tanah tidak diperhatikan.

Dalam model jNSM, data yang diperlukan adalah curah hujan, suhu udara, suhu tanah, Water Holding Capacity (WHC) yang diperoleh dari pedoman menurut Thornthwaite dan Mater (1957) dengan memperhatikan tekstur tanah dan vegetasi. Prosedur dalam perhitungan neraca air menurut NRCS Java Newhall Simulation Model (jNSM) menggunakan langkah-langkah sebagai berikut: (1) Pengukuran tekstur tanah; (2) Pengumpulan data curah hujan; (3) Pengumpulan data suhu udara; (4) Pengumpulan data suhu tanah; (5) Analisis perbedaan bulanan suhu udara dengan suhu tanah; (6) Melakukan input data curah hujan, suhu udara, perbedaan suhu tanah dan udara, kemampuan tanah memegang air atau water holding capacity (WHC), nama dan koordinat stasiun penangkar hujan kemudian di-run. Hasil analisis neraca air tanah kemudian dipetakan dengan menggunakan sistem informasi geografis (SIG) sehingga dapat diketahui wilayah yang mengalami periode defisit maupun surplus air. Data surplus dan defisit air bulanan akan digunakan sebagai informasi untuk menentukan pola tanam.

\section{HASIL DAN PEMBAHASAN}

\section{Gambaran Wilayah Kecamatan Lewa}

Secara administratif, kecamatan lewa berbatasan dengan Kecamatan Haharu di sebelah Utara, Kecamatan Lewa Tidahu di sebelah Selatan, Nggaha Ori Angu di sebelah Timur, dan Kabupaten Sumba Tengah di sebelah Barat. Kecamatan Lewa memiliki luas wilayahnya kurang lebih 28.100 ha yang terdiri dari 1 Kelurahan dan 7 desa yaitu Kelurahan Lewa Paku, Desa Tanarara, Desa Kambu Hampang, Desa Kondamara, Desa Matawai Pawali, Desa Rakawatu, Desa Bidihunga. Kecamatan Lewa berada di ketinggian antara 500-669 m dpl (BPS, 2015). Komoditi pangan utama yang dibudidayakan adalah padi dan jagung yang dapat dilihat luasan dan produksinya pada Tabel 1.

\section{Curah Hujan dan Suhu Udara}

Curah hujan dan suhu merupakan faktor-faktor yang mempengarui kondisi ketersediaan air suatu wilayah. Curah hujan merupakan sumber pasokan air di permukaan bumi yang akan mendistribusikan sesuai dengan siklus air. Sebagai sumber pasokan air, maka curah hujan sangat penting untuk keberlangsungan keberadaan air di permukaan bumi (Wijayanti dkk., 2015). Berdasarkan hasil analisis data curah hujan bulanan dari tahun 2000-2015 di delapan stasiun klimatologi (Tabel 2). Rerata curah hujan tahunan di

Tabel 1. Data luas panen, produksi, dan produktivitas tanaman padi dan jagung

\begin{tabular}{cccc}
\hline Jenis Tanaman & $\begin{array}{c}\text { Luas Panen } \\
\text { (ha) }\end{array}$ & Produksi (ton) & $\begin{array}{c}\text { Produktivitas } \\
\text { (kw/ha) }\end{array}$ \\
\hline Padi & 2.046 & 7.802 & 38.13 \\
Jagung & 599 & 1.136 & 30,89 \\
\hline
\end{tabular}

Sumber: Badan Pusat Statistik (2015) 
Kecamatan Lewa antara 1.360-1.949 mm/tahun. Curah hujan ini sangat sesuai untuk tanaman padi dan cukup sesuai untuk tanaman jagung. Tanaman padi pada umumnya membutuhkan curah hujan yang baik ratarata $200 \mathrm{~mm}$ per bulan atau lebih, dengan distribusi selama 4 bulan, dan curah hujan yang dikehendaki pertahun sekitar 1500-2000 mm (Paski dkk., 2018). Jagung memerlukan cukup air pada fase pembungaan dan pengisian biji, akan tetapi tidak cocok di lahan yang terdapat air yang menggenang. Curah hujan yang ideal sekitar 85-200 mm/bulan dan harus merata. Jagung sangat sesuai di daerah dengan curah hujan sekitar 807-1.200 mm/tahun (Wirosoedarmo dkk., 2011).

Suhu udara akan mempengaruhi ketersediaan air tanah melalui mekanisme besarnya evapotranspirasi. Nilai suhu udara berfluktuasi terhadap nilai evapotranspirasi yaitu terjadinya kenaikan dan penurunan suhu disertai kenaikan dan penurunan evapotranspirasi, hal ini disebabkan oleh unsurunsur iklim (Simanjuntak dkk 2016). Setiap tanaman membutuhkan suhu yang optimal dalam setiap proses pertumbuhannya. Suhu yang terlalu tinggi atau terlalu rendah akan menghambat pertumbuhan tanaman bahkan dapat mematikan tanaman (saputra, 2018). Berdasarkan hasil interpretasi citra satelit Lansat 7 ETM+ (band 61 dan band 62) untuk tahun 2007-2012 dan citra Lansat 8 OLI/TIRS Path/Row 118/065 untuk tahun 2013-2017, diperoleh suhu udara di delapan stasiun klimatologi seperti tersaji pada Gambar 1. Dari
Gambar 1, bahwa rata-rata suhu udara bulanan berkisar antara $21,6^{\circ} \mathrm{C}$ hingga $24,1^{\circ} \mathrm{C}$. Rentang suhu ini sangat sesuai untuk tanaman padi dan jagung. Hal ini sesuai dengan pendapat Paski dkk. (2018) bahwa suhu udara yang baik untuk pertumbuhan tanaman padi berkisar $19-27^{\circ} \mathrm{C}$, namun suhu yang paling ideal adalah sekitar $23{ }^{\circ} \mathrm{C}$ dan suhu udara yang baik untuk pertumbuhan tanaman jagung yaitu $23-27^{\circ} \mathrm{C}$ dengan suhu optimal $25^{\circ} \mathrm{C}$.

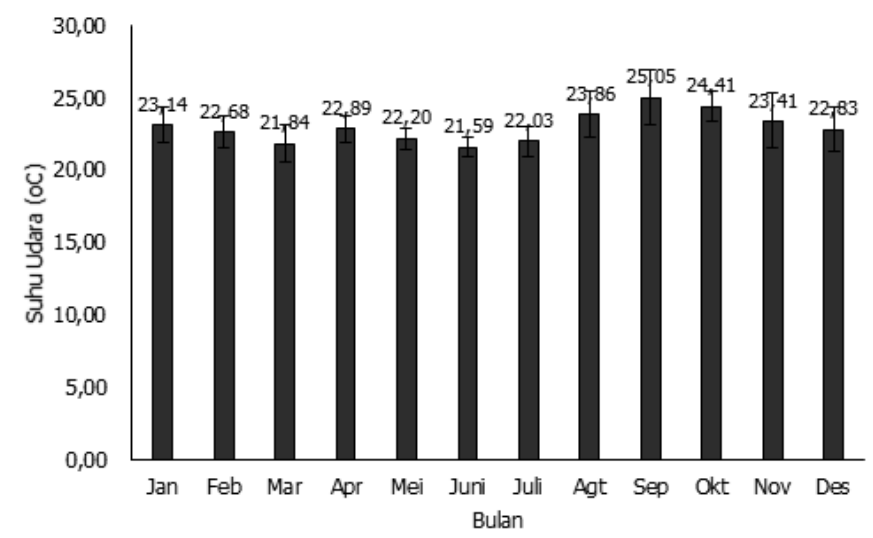

Keterangan: standar deviasi bulan Januari 1,26; Februari 1,15; Maret 1,26; April 0,93; Mei 0,74; Juni 0,69; Juli 1,04; Agustus 1,58; September 1,89; Oktober 1,02; November 1,90; Desember 1,50.

Gambar 1. Grafik rata-rata suhu bulanan bulanan $\left({ }^{\circ} \mathrm{C}\right)$ tahun 2007-2016

Tabel 2. Rata-rata curah hujan bulanan (mm) dari tahun 2000-2015

\begin{tabular}{ccccccccc}
\hline Bulan & \multicolumn{7}{c}{ Stasiun klimatologi } \\
\hline Januari & Malahar & Melolo & Ngongi & Waingapu & Tanarara & Wanga & Kananggar & Lindiwacu \\
Februari & 334,04 & 113,38 & 297,19 & 160,87 & 248,67 & 189,31 & 293,82 & 443,00 \\
Maret & 419,83 & 143,38 & 296,32 & 173,75 & 200,50 & 152,31 & 262,00 & 397,71 \\
April & 312,84 & 114,00 & 199,98 & 158,81 & 150,23 & 136,77 & 259,55 & 282,86 \\
Mei & 198,75 & 156,00 & 138,23 & 99,32 & 103,42 & 98,31 & 113,59 & 231,57 \\
Juni & 54,67 & 44,38 & 62,97 & 25,28 & 26,50 & 19,69 & 66,32 & 102,00 \\
Juli & 14,46 & 8,38 & 58,00 & 12,27 & 15,83 & 3,08 & 20,14 & 14,13 \\
Agustus & 8,54 & 1,63 & 15,45 & 7,13 & 4,50 & 2,00 & 11,05 & 4,86 \\
September & 2,29 & 0 & 8,77 & 0,50 & 0,50 & 0 & 6,59 & 0 \\
Oktober & 10,71 & 1,38 & 28,90 & 4,23 & 14,83 & 0,62 & 9,86 & 102,14 \\
November & 89,08 & 9,88 & 24,55 & 11,80 & 10,67 & 1,38 & 16,18 & 72,14 \\
Desember & 240,16 & 41,13 & 99,84 & 54,13 & 94,33 & 38,23 & 121,68 & 211,14 \\
Total & 303,79 & 132,88 & 208,94 & 147,77 & 131,52 & 168,31 & 259,23 & 112,00 \\
Rata-rata & 1.989 & 766 & 1.439 & 856 & 1.001 & 810 & 1.440 & 1.974 \\
Stan. Dev. & 165,76 & 63,86 & 119,93 & 71,32 & 83,46 & 67,50 & 120,00 & 164,46 \\
\hline
\end{tabular}




\section{Evapotrasnpirasi Potensial}

Evapotranspirasi potensial (ETP) adalah besarnya evapotranspirasi pada suatu lahan pertanaman jika air mencukupi dan pertumbuhan tanaman tidak terganggu atau dengan pengertian lain evapotranspirasi yang terjadi jika tanah dalam keaadan tidak kurang air dan seluruh vegetasi di atanya menutupi permukaan tanah (Thornthwaite, 1948 dalam Nuryanto dan Rizal, 2014). Data evapotranspirasi potensial dapat digunakan untuk menganalisis tingkat ketersediaan air tanah dilengkapi

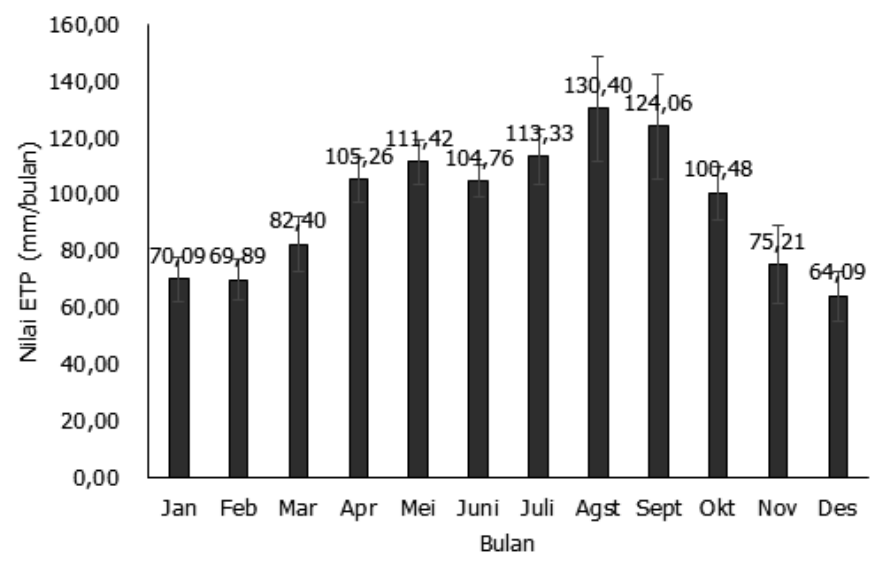

Keterangan: standar deviasi bulan Januari 7,80; Februari 7,10; Maret 9,58; April 7,72; Mei 7,71; Juni 5,65; Juli 9,45; Agustus 18,55; September 18,35; Oktober 9,65; November 13,60; Desember 8,65.

Gambar 2. Grafik rata-rata evapotranspirasi potensial bulanan (mm/bulan) dengan data curah hujan, suhu, dan kandungan air tanah (legas tanah). Hasil analisis data curah hujan, suhu udara, suhu tanah dan kemampuan tanah mengikat air dengan menggunakan software jNSM diperoleh data rata-rata evapotranspirasi potensial dari 8 stasiun klimatolgi seperti tersaji pada Gambar 2. Ratarata evapotranspirasi potensial tahunan dari ke delapan stasiun klimatologi adalah $1.151 \mathrm{~mm} /$ tahun. ETP tertinggi terjadi pada bulan Agustus sebesar 130,40 mm/bulan dengan suhu rata-rata $23,9^{\circ} \mathrm{C}$ dan curah hujan ratarata $2,33 \mathrm{~mm} /$ bulan. Adapun ETP terendah pada bulan Desember sebesar $64,09 \mathrm{~mm} /$ bulan dengan suhu udara sebesar $22,8^{\circ} \mathrm{C}$ dan curah hujan $183,05 \mathrm{~mm} /$ bulan. Perbedaan nilai ETP ini dipengaruhi oleh faktor iklim dan keadaan kondisi tanah setempat (Mooree dkk., 2011; Helena dan Daniel, 2012 dalam Tufaila dkk., 2017).

\section{Neraca Air}

Neraca air merupakan model hubungan kuantitatif antara jumlah air yang tersedia di atas dan di dalam tanah dengan jumlah curah hujan yang jatuh pada luasan dan kurun waktu tertentu (Ayu dkk., 2013). Menurut Jeckson (1977) dalam Simanjuntak dkk. (2016), neraca air merupakan perimbangan yang terjadi antara curah hujan $(P)$ dan laju evapotranspirasi potensial (ETP). Apabila curah hujan melebihi evapotranspirasi potensial ( $P>E T P)$, maka terjadi peningkatan air tanah sehingga air cukup tersedia bahkan lahan mengalami kelebihan air atau surplus (S), dan sebaliknya jika curah hujan lebih kecil dari evapotranspirasi potensial $(P<E T P)$, akan berkurang kandungan air dalam tanah bahkan

Tabel 3. Kandungan air tanah bulanan ( $\mathrm{mm} /$ bulan) dan kondisi surplus/defisit air tanah

\begin{tabular}{|c|c|c|c|c|c|c|c|c|c|c|c|c|c|}
\hline \multirow{2}{*}{$\begin{array}{l}\text { Stasiun } \\
\text { klimatologi }\end{array}$} & \multicolumn{12}{|c|}{ Kandungan air tanah (mm) } & \multirow{2}{*}{$\begin{array}{c}\text { Total air } \\
\text { tanah } \\
\text { tahunan }\end{array}$} \\
\hline & Jan & Feb & Mar & Apr & Mei & Juni & Juli & Ags & Sep & Okt & Nov & Des & \\
\hline Malahar & 262,5 & 353,4 & 235,0 & 98,5 & $-52,0$ & $-88,1$ & $-109,5$ & $-154,2$ & $-112,7$ & 2,1 & 182,1 & 251,0 & 868,2 \\
\hline Melolo & 33,1 & 63,8 & 29,3 & 45,8 & $-61,7$ & $-91,5$ & $-124,7$ & $-134,0$ & $-146,5$ & $-104,0$ & $-51,9$ & 61,4 & $-480,9$ \\
\hline Ngongi & 232,2 & 231,0 & 119,5 & 34,7 & $-55,3$ & $-46,6$ & $-95,3$ & $-113,1$ & $-71,0$ & $-83,6$ & 27,4 & 146,7 & 326,5 \\
\hline Waingapu & 94,0 & 109,3 & 74,5 & $-9,8$ & $-90,4$ & $-104,5$ & $-106,1$ & $-158,4$ & $-138,9$ & $-86,7$ & $-23,5$ & 78,8 & $-361,6$ \\
\hline Tanarara & 189,9 & 137,1 & 79,9 & 7,8 & $-78,0$ & $-82,6$ & $-94,7$ & $-123,2$ & $-99,0$ & $-83,7$ & 33,9 & 80,8 & $-31,8$ \\
\hline Wanga & 109,0 & 72,7 & 52,0 & $-12,0$ & $-85,0$ & $-96,9$ & $-124,4$ & $-132,5$ & $-147,3$ & $-112,5$ & $-54,8$ & 96,8 & $-434,8$ \\
\hline Kananggar & 232,3 & 199,3 & 186,6 & 19,1 & $-41,8$ & $-88,1$ & $-90,4$ & $-93,8$ & $-96,1$ & $-74,8$ & 60,6 & 199,7 & 412,7 \\
\hline Lindiwacu & 366,7 & 320,2 & 179,0 & 113,0 & $-25,4$ & $-93,4$ & $-106,4$ & $-115,4$ & $-8,4$ & $-25,0$ & 125,0 & 36,3 & 766,3 \\
\hline Rata-Rata & 189,9 & 185,8 & 119,5 & 37,1 & $-61,2$ & $-86,5$ & $-106,4$ & $-128,1$ & $-102,5$ & $-71,0$ & 37,4 & 119,0 & 133,1 \\
\hline Sta. Deviasi & 107,2 & 109,7 & 73,3 & 46,9 & 22,3 & 17,4 & 13,0 & 21,5 & 46,7 & 39,4 & 84,0 & 74,1 & \\
\hline $\begin{array}{l}\text { Kondisi surplus/ } \\
\text { defisit air tanah }\end{array}$ & S & S & $S$ & S & D & D & D & D & $D$ & D & S & $S$ & \\
\hline
\end{tabular}

Keterangan: $S=$ Surplus Air, $D=$ Defisit Ait 
dapat mencapai keadaan defisit (D) (Musyadik dan Masetyowati, 2014).

Berdasarkan hasil data analisis data curah hujan, suhu udara, suhu tanah, dan kapasitas tanah menyimpan air dengan menggunakan software jNSM diperoleh data ketersediaan air di tanah bulanan 8 stasiun klimatologi (Wanga, Tanarara, Ngongi, Malahar, Kananggar, Melolo, Waingapu, dan Lindiwacu) yang tertera pada Tabel 3. Dari Tabel 3 bahwa ketersediaan air tanah surplus (S) pada bulan November, Desember, Januari, Februari, Maret, April, sedangkan defisit (D) terjadi pada bulan Mei, Juni, Juli, Agustus, September, Oktober. Kondisi surplus air yang terjadi karena nilai curah hujan lebih tinggi dari nilai evapotranspirasi potensial yang terjadi, sedangkan kondisi defisit terjdai karena nilai curah hujan lebih kecil dari nilai evapotranspirasi potensial. Menurut Tufaila dkk. (2017), kondisi surplus dan defisit ini disebabkan oleh beberapa faktor diantaranya kondisi iklim, karakteristik lahan serta jenis tanah yang

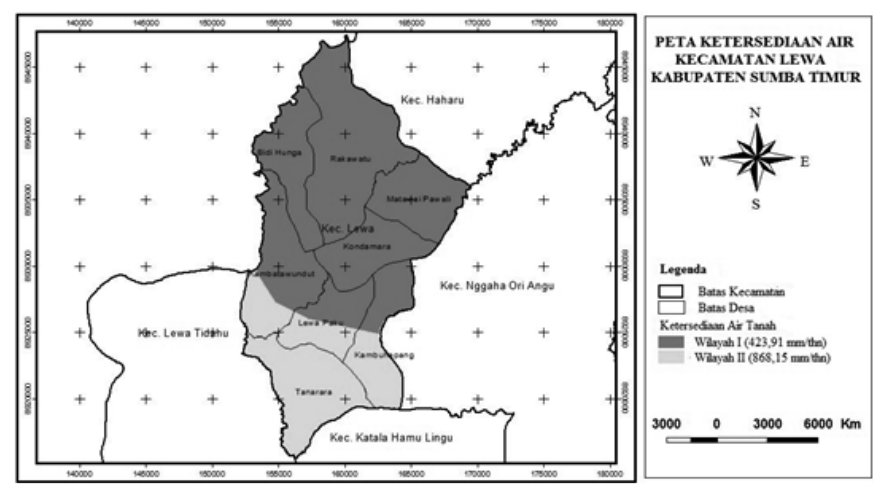

Sumber: Hasil olah data 2018

Gambar 3. Peta neraca air tahunan kecamatan Lewa ada di lokasi penenlitian, dan yang paling dominan mempengaruhi neraca air adalah kondisi iklim.

Berdasarkan hasil interpolasi data ketersedian air tahunan menggunakan software Arcview, terdapat 2 zona (Gambar 3). Zona I memiliki ketersediaan air tanahnya 413 mm/tahun yang mencakup desa Bidi Hunga, Rakawatu, Matawai Pawali, Kondamara, sebagian desa Kambatawundut, sebagian Kelurahan Lewa Paku, dan sebagian desa Kambuhapang. Sedangkan zona II memiliki ketersediaan air $868 \mathrm{~mm} /$ tahun, mencakup desa Tanarara, sebagian keluran Lewa Paku, sebagian desa Kambatawundut, sebagian desa Kambuhapang.

\section{Pola Tanam}

Kecamatan Lewa merupakan daerah lahan kering yang semua aktivitas pertaniannya menggunakan sumber mata air dari air hujan, sehingga ketersedian air sangat berpengaruh terhadap pola tanam. Status dan pola Ketersediaan air di tanah suatu wilayah merupakan faktor utama penentu pola tanam untuk tanaman semusim pada di lahan kering/tadah hujan. Pola tanam lahan kering/tadah hujan sangat sangat erat kaitannya oleh lamanya musim tanam (lengthgrowing season) yang sepenuhnya ditentukan oleh ketersediaan air bagi tanaman (Mardawilis dkk., 2011). Penyusunan pola tanam merupakan bentuk adaptasi manusia dalam memanfaatkan potensi cuaca suatu wilayah. Adaptasi dapat dikatakan sebagai upaya yang membutuhkan sedikit input teknologi nampu butuh perencanaan yang matang, yaitu butuh informasi yang panjang untuk mengetahui karakteristik iklim wilayah yang akan dikembangkan (Effendy, 2000 dalam Mardawilis dkk., 2011).

Tabel 4. Rancangan masa tanam dan pola tanam Kecamatan Lewa

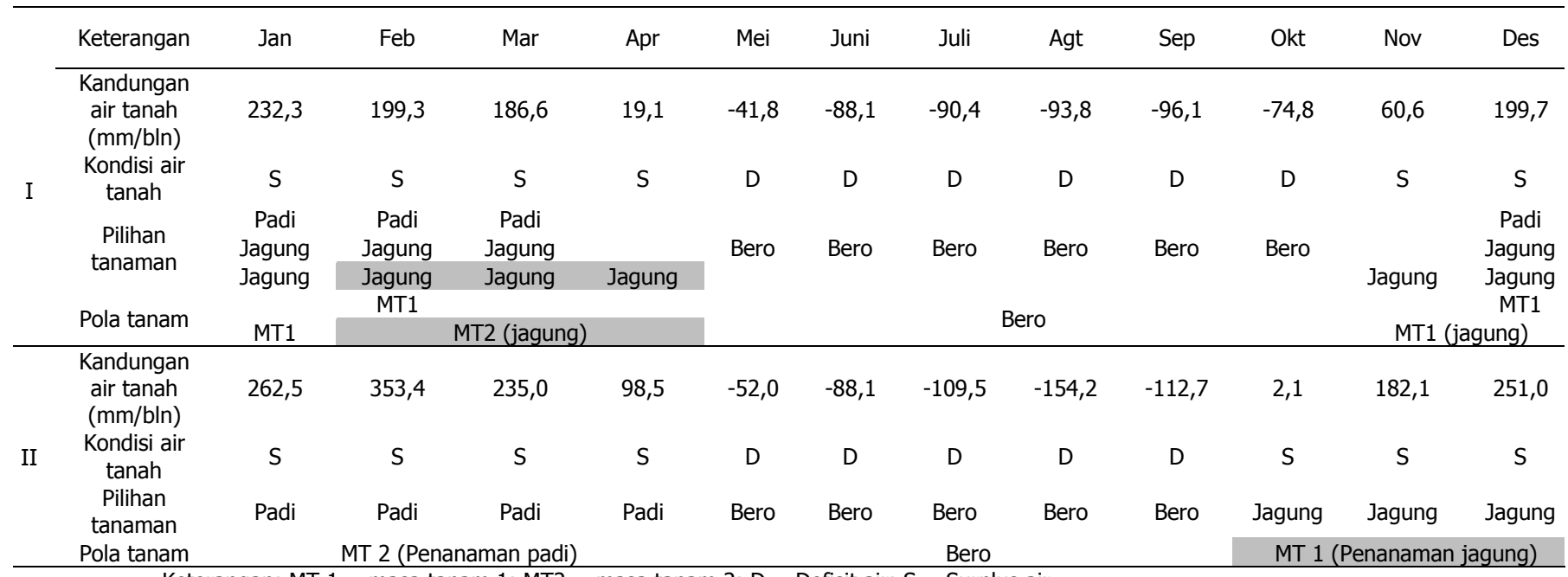


Hasil interpolasi data neraca air dari 8 stasiun klimatologi menggunakan software Arcview, menunjukan bahwa wilayah Kecamatan Lewa terdapat 2 zona. Berdasarkan ketersediaan airnya, dapat ditentukan pola tanam pada masing-masing zona seperti tersaji pada Tabel 4: (1) Zona I dapat dilakukan penanaman dengan 1 kali dengan tanaman padi/jagung yang ditanam pada bulan Desember dan dipanen pada bulan Maret. Akan tetapi wilayah ini dapat dioptimalkan dengan penanaman 2 kali menggunakan tanaman jagung yang berumur pendek yang ditanam serentak pada bulan NovemberJanuari (MT1) dan Feburari-April (MT2). Sedangkan pada bulan Mei sampai bulan Oktober lahan akan dibiarkan bera (tanpa budidaya) karena ketersediaan ait tidak memadai; (2) Zona II dapat dilakukan penanaman 2 kali dalam setahun dengan pola yaitu masa tanam I (MT I) berlangsung dari bulan Oktober-Desember dengan tanaman jagung dan masa tanam II (MT II) berlangsung dari bulan Januari-April tahun berikutnya dengan tanaman padi atau jagung. Selain itu dapat juga dilakukan penanaman 1 kali yaitu dari bulan Desember sampai Maret dengan pilihan tanaman jagung atau padi.

\section{KESIMPULAN}

Analisis jNSM dan interpolasi data ketersedian air tahunan di Lewa menghasilan 2 zona. Pada zona I memiliki ketersediaan air $413 \mathrm{~mm} /$ tahun dan zona II 868 $\mathrm{mm} /$ tahun. Berdasarkan kondisi surplus dan defisit air, maka dapat dirancang pola tanam di dua zona tersebut. Zona I hanya dapat ditanami satu kali dalam setahun, yaitu di musim hujan (Desember-April) dengan pilihan tanaman padi atau jagung. Zona II memungkinkan ditanam dua kali dengan memaksimalkan potensi hujan dari bulan Oktober-April dengan jagung-padi atau jagung-jagung.

\section{DAFTAR PUSTAKA}

Ayu, I. W., Prijono, S., \& Soemarno. (2013). Evaluasi Ketersediaan Air Tanah Lahan Kering di Kecamatan Unter Iwes, Sumbawa Besar. J-Pal, 4(1), 18-25.

Badan Pusat Statistik (BPS). (2015). Kabupaten Sumba Timur dalam Angka 2015. Kabupaten Sumba Timur: Badan Pusat Statistik.

Dauglas, A. M., \& Brian, B. (2011). jNSM 1.6.0 - Java Newhall Simulation Model. CESU 68-7482-9-527 Enchanced Newhall Simulation Model Project. Center for Environment Information. Pennstate University USA.

Djufry, F. (2012). Pemodelan neraca air tanah untuk pendugaan surplus dan defisit air untuk pertumbuhan tanaman pangan di Kabupaten Marauke, Papua. Informatika Pertanian, 21(1), 1-9.

Hidayat, T., Koesmaryono, Y., \& Pramudia, A. (2006). Analisis Neraca Air dalam Penentuan Potensi Musim Tanam Tanaman Pangan di Provinsi Banten. J. Floratek, 2, 5562.

Hidayat, T., Koesmaryono, Y., \& Pramudia, A. (2006). Analisis Neraca Air untuk Penetapan Periode Tanam Tanaman Pangan di Propinsi Banten. Indonesia Agromet, 20(1), 44-51.

Karamouz, M., Zahraie, B., Kerachian, R., \& Eslami, A. (2010). Crop pattern and conjunctive use management: A case study. Irrigation and Drainage, 59(2), 161-173. https:// doi.org/10.1002/ird.457

Karnadi. (2012). Kajian Pola Tanam Pada Lahan Gambut Kecamatan Sungai Raya Kabupaten Kubu Raya (Studi Kasus Desa Limbung). Teknik Sipil Untan, 12(2), 191202.

Makaborang, M., Goenadi, S., \& Hadi, P. (2009). Optimasi Penggunaan Lahan Berdasarkan Kelas Kesesuian Lahan Untuk Pengembangan Tanaman Perkebunan (Studi Kasus: Kabupaten Sumba Timur Provinsi Nusa Tenggara Timur). Agritech, 29(4), 188-197.

Mardawilis, Sudira, P., Sunarminto, B. H., \& Shiddiq, D. (2011). Analisi Neraca Air Untuk Pengambangan Tanaman Pangan Pada Kondisi Iklim Yang Berbeda. Agritech, 31(2), 109-115.

Musyadik, A., \& Masetyowati, T. (2014). Penentuan Masa Tanam Kedelai Berdasarkan Analisis Neraca Air Di Kabupaten Konawe Selatan, Sulawesi Tenggara. Widyariset, 17(2), 277-282.

Nuryanto, D. E., \& Rizal, J. (2014). Perbandingan Evapotranspirasi Potensial Antara Hasil Keluaran Model ReGCM 4.0 dengan Perhitungan Data Pengamatan. Meteorologi Dan Geofisika, 14(2), 75-85.

Paski, J. A. I., Faski, G. I. S. L., Handoyo, M. F., \& Pertiwi, D. A. S. (2018). Analisis Neraca Air Lahan untuk Tanaman Padi dan Jagung Di Kota Bengkulu. Jurnal Ilmu Lingkungan, 15(2), 83. https://doi.org/10.14710/jil.15.2.83-89

Simanjuntak, B. H., Agus, Y. H., \& Yulianto, S. (2016). Kajian Ketersediaan Air Tanah Untuk Penentuan Surplus-Defisit Air Tanah Dan Pola Tanam. In Konser Karya Ilmiah Nasional (pp. 113-124). Salatiga: Fakultas Pertanian dan Bisnis Unversitas Kristen Satya Wacana.

Tufaila, M., Mpia, L., \& Karim, J. (2017). Analisis Neraca Air Lahan pada Jenis Tanah yang Berkembang pada Daerah Karts di Kecamatan Parigi Kabupaten Muna Sulawesi Tenggara. Agritech, 37(2), 215-219. https://doi. org/10.22146/agritech.16747

Utomo, M., Sabrina, T., Sudarsono, Lumbanraja, J., Rusman, B., \& Wawan. (2016). Ilmu Tanah: Dasar-dasar dan Pengelolaan. Jakarta: Prenadamedia Group. 
Wirosoedarmo, R., Sutanhaji, A. T., Kurniati, E., \& Wijayanti, R. (2011). Evaluasi kesesuaian lahan untuk tanaman jagung menggunakan metode analisis spasial. Agritech, 31(1), 71-78. https://doi.org/https://doi.org/10.22146/ agritech. 9728
Wiweka. (2014). Pola Suhu Permukaan dan Udara Menggunakan Citra Satelit Landsat Multitemporal. Ecolab, 8(1), 11-22. 